\title{
STRUCTURAL CHANGES IN THE DEVELOPMENT OF EUROPEAN CO-OPERATIVE SOCIETES
}

\author{
by \\ Josefina FERNÁNDEZ GUADAÑO* \\ Universidad Complutense de Madrid, Spain
}

\begin{abstract}
In spite of the wealth of experience which co-operative societies now have behind them, they have not gained uniform recognition across Europe. Supranational authorities such as the European Commission, the UN and the ILO have highlighted the important contribution made by co-operative societies in the creation of employment and in the mobilization of resources particularly at the local level. For several years now, however, two different tendencies in the development of the European co-operative movement are becoming apparent and they are analysed in this study. One is towards the creation of growth processes through formulas which aim to bring under the same roof asset holders who by their very nature are a difficult fit, all the while trying to maintain certain cooperative principles. And on the other hand, a tendency towards the creation of micro-companies that act in local markets and allow for territorial development by means of the mobilization of local resources, based on local allegiance of the partners and democratic participation.
\end{abstract}

\section{$1 \quad$ Introduction}

Co-operative societies have aroused increasing interest in Europe and reflect the demands of a changing society for the development of socially responsible initiatives within the field of economics. Characteristic principles of co-operative societies such as the freedom to participate in productive processes, democracy and shared

\footnotetext{
* The author is grateful to the referees for suggestions that were indispensable in improving this work. Email: jfernandezguadao@ccee.ucm.es ** Résumé en fin d'article; Zusammenfassung am Ende des Artikels; resumen al fin del artículo.

C CIRIEC 2006. Published by Blackwell Publishing Ltd, 9600 Garsington Road, Oxford OX4 2DQ, UK and 350 Main Street, Malden, MA 02148, USA
} 
responsibility for outlining general objectives, and fair profit distribution (García-Gutiérrez 1991: 197) have made them, together with the rest of the organizations that comprise the Social Economy, a worthy alternative to both the public and the private capitalist economy.

Moreover, according to the latest conclusions by the European Social Economy Conference held in Salamanca in 2002, ${ }^{1}$ the European Commission recognizes: that all forms of Social Economy businesses have, in many sectors, become a viable alternative to the maintenance of a welfare state. This is because of their capacity to generate employment, and more importantly, to encourage a capacity for enterprise. It is also because they aim to facilitate social cohesion and integration by opening up creative business opportunities to collectives in particularly vulnerable socialeconomic situations, because they meet new social needs overcoming insufficiencies in an inadequate system of social protection to meet specific needs, and because in driving forward a different globalization which is just as viable, they provide a link between economic growth and social cohesion.

Today the recognition enjoyed by co-operative societies from the European authorities is highlighted by various initiatives: the creation of a social economic unit within the DG Enterprise, ${ }^{2}$ the holding of a Permanent European Conference of Co-operatives, Mutual societies, Associations and Foundations (PEC-CMAF), ${ }^{3}$ the development of the $\mathrm{ARIES}^{4}$ information network, the creation of SOFICATRA ${ }^{5}$ and through financial support from Structural Funds from the European Union.

Recognition of co-operative societies by such bodies as the European Union, the United Nations (2004), ${ }^{6}$ and the International Labour Office $(2002)^{7}$ highlight the contribution made by these co-operative societies to

1 See: Conclusions of the VIII European Conference on Social Economy (2002) Avaible on Internet: http://www.europa.eu.int/comm/enterprise/ entrepreneurship/coop/conferences/coop-conferences-index.htm.

2 Available on Internet: http://www.europa.eu.int/comm/enterprise/ entrepreneurship/coop/index.htm. Last consulted [19th August 2004]

3 Available on Internet: http://www.europa.eu.int/comm/enterprise/ entrepreneurship/coop/social-cmaf_agenda.htm. Last consulted [19th August 2004]

4 Available on Internet: http://www.aries.eu.int. Last consulted [19th August 2004]

5 An economic institution providing investments in European Social Economy projects.

6 Available on Internet: http://www.copacgva.org/unpubs.htm\#unres. Last consulted [31th January 2005]

7 Available on Internet: ilo.org/ilolex/cgi-lex/convde.pl?R193. Last consulted [31th January 2005] 
the economy via the creation of employment, the mobilization of resources and the generation of investment. Furthermore, and of greatest importance, is their role in promoting the greatest possible participation of the general population in social and economic development.

Since their origins, the strength of co-operative societies, and what has differentiated them from other third sector organizations, has been their commitment to co-operative principles (ICA, 1995). ${ }^{8}$ These are the guidelines through which co-operative societies put into practice their values of self-help, self-responsibility, democracy, equality, equity and solidarity.

The practices of a number of societies or co-operative groups ${ }^{9}$ raise the question of whether or not certain co-operative principles are in fact being respected. The cause lies in the overriding need of these businesses to adapt to an economic climate which forces them (as it does any kind of business) towards growth via mergers. However, these changes can run counter to the spirit that initially inspired the mutual societies. Co-operative societies that reduce the rights and obligations of their members to a minimum, to the extent that members resemble mere clients and suppliers, lapse into capitalistic forms of behaviour; increasing the volume of operations with third (non-partners) parties; and opening the corporate structure of the cooperative society to new types of partners.

This process of isomorphism, ${ }^{10}$ which threatens to compromise the co-operative identity by luring it away from the Social Economy and towards the conventional capitalist economy, is analysed in this study.

Alongside this isomorphism process we find co-operative microbusiness initiatives. This is the formula chosen by many groups of

\footnotetext{
8 Available on Internet: http://www.ica.coop/ica/es/esprinciples.html. Last consulted [31th January 2005]

9 A co-operative group is understood as a group made up of various co-operative societies, independent of their type, and the entity at the head of the group exercises powers or sends out instructions that must be complied with by the co-operatives in the group. In this way, there is a unity of decisionmaking in the area of said powers. One example of a successful co-operative international group is Mondragón Corporación Cooperativa. It can be consulted at: http://www.mcc.es/

10 The 'isomorphism' process implies the abandonment of the mutualization principles that have characterized the cooperative societies since their origin. If in the past the cooperative society had to become a mutual company to fulfil its main function - dignify the conditions of life of its members - today and in the future the cooperative society has to open itself to the market, rather than pursuing the exclusive satisfaction of its partners' needs.
} 
citizens as a way of either finding a place in the labour market or as form of social cohesion to provide for the needs of disadvantaged collectives.

Co-operative micro-business also provides a separate response to globalization as members are offered greater opportunities for involvement in their field and will feel a more profound sense of belonging to the organization itself. This is why the European Union has underlined the important role played by co-operative societies in local development. ${ }^{11}$

In recent years co-operative societies have broadened their activities to encompass emerging social needs. In order to attain these objectives they find themselves in direct competition with other entities within the third sector such as associations, mutuals and foundations. These initiatives are responses to processes of privatization, reorientation of objectives and forms of welfare state intervention.

In conclusion, this study will analyse the process of structural change which the co-operative societies in Europe have been undergoing in recent years. In order to achieve this, data is used to illustrate the current situation; the two different tendencies affecting the co-operative movement, mergers and micro-business, are also described.

\section{Tendencies within the co-operative societies in Europe}

Since its conception the co-operative movement has attempted to provide answers to the latent economic and social problems faced by those in the most vulnerable strata of society. Furthermore the Social Economy movement arose in Europe as a way for the working classes to secure a better livelihood and ensure their access to the consumer society. In recent years, it has taken on a new function, that of providing a service of social reintegration (Demoustier 2000: 51-52).

According to data provided by the ICA (1998), there are over 132,000 co-operative societies currently in existence in Europe. They provide employment to 2.3 million people and have a joint membership of 83.5 million. Information on employment generated by co-operative societies in large part agree with the figures given in a

11 European Communities. Resolution on the contribution of co-operatives to regional development. Official Journal of the European Communities (O.J.E.C.), n. ${ }^{\circ} \mathrm{C}$ 61, 11th February 1994. 
study carried out by CIRIEC for the European Commission (2000) which calculated employment in the co-operative society area at 2,286,039 jobs.

However, regardless of their role or of the recognition achieved in each European country, co-operative societies are faced with problems similar to those of any conventional capitalist business. Challenges arise from organizational changes, variations in demand, an increase in competition, the reorientation of objectives or the way the welfare state influences in the economy. Furthermore, they face additional difficulties, derived from their very nature: how to comply with co-operative principles.

In response to these changes, in Europe different tendencies in the development of cooperativism are becoming apparent. On one hand, there is a movement on the part of some co-operative societies towards mergers; on the other hand, there are business initiatives to emphasize micro-business investment. The path followed apparently reflects the difference between traditional and new co-operatives outlined by Sätre (2001): 'while traditional co-operatives have been contracting due to an increasing degree of competition, new cooperatives due to their small-scale seem to face a more positive progress providing a model for the integration of socially excluded and promoting local development'.

\section{Co-operative mergers: the risk of isomorphism}

Business concentrations have, in recent years, become a factor of considerable importance in all economic activities and have affected all legal forms of enterprise. Co-operatives too have felt the need to expand in the market through business mergers which help them to adapt their structures to the demands of the global market.

In cases where there is a need to adapt to circumstances, a large scale business merger can be a genuine survival technique even though these large corporations have inherent difficulties in integrating standard co-operative forms of management (Parra de Mas 1974: 5). For this reason co-operative mergers must simultaneously take into account aspects of business as well as those norms which differentiate and characterize co-operative societies: co-operative principles (García-Gutiérrez, 1994: 421).

One of these principles actually sets out to encourage this kind of process. The Principle of Intercooperation, following the 1995 Manchester Conference, was defined thus (ICA, 1995): 'Co-operatives 
serve their members as efficiently as possible and strengthen the co-operative movement by working together through local, national, regional and international structures'.

Co-operation between co-operatives is a response to the ideological challenge to the preservation of Principle of Intercooperation, and the search for formulas which, based on this premise, will raise the capacity of co-operatives to influence their environment. It is also clear however, that this current economic trend could result in co-operatives establishing alliances with other kinds of businesses (Vargas 1999: 296). The first instance could be considered strict intercooperation while the second could be considered broad cooperation.

This broader intercooperation is what has been highlighted by isomorphism or the tendency by large co-operatives either to slide towards capitalist forms of societies, to create instrumental commercial corporations as a flexible form of growth, to involve themselves in large scale mergers projects with companies outside the third sector and has been the response of many highly successful co-operatives in the fields of banking, retail and agriculture. ${ }^{12}$ According to Defourny (1994: 132) once co-operatives have grown to sizable proportions, many adopt conduct and strategies which differ less and less from those of their competitors. This has been called 'cooptalismo' (Belley 1988), 'isomorphism' (Bager 1994, Chaves 1997), or 'decooperativization' (Vivet and Thiry 2000: 18).

In concordance with an empirical analysis undertaken by Bager (1994: 53-54), over the last decades co-operatives have frequently undergone a complete or partial transformation into other types of businesses or hybrid organizations. This transformation appears to be all the greater when faced with a combination of strong outside pressure and internal weaknesses.

According to a study by Ciriec (Barea et al. 1999) in Spain the main co-operative groups Mondragón Corporación Cooperativa (MCC), Group Cooperative of Valencia (GECV) and Agriculture Group ANECOOP, use capitalist business structures as a form of expansion. Nonetheless, the strategy of the 'second degree co-operative ${ }^{, 13}$ or 'co-operative group', ${ }^{14}$ structures of a higher degree by integrating other co-operative societies, are recognized in Spanish

12 See practical examples in Barea J., Juliá J.L. and Monzón J.L. (Dres) (1999) Grupos empresariales de la Economía social en España. Valencia: CIRIEC-España.

13 SPAIN. Law 27/1999, 16 July, Co-operatives. $B O E, \mathrm{n}^{\circ} .170$, article 77.

14 SPAIN. Law 27/1999, 16 July, Co-operatives. BOE, $\mathrm{n}^{\circ} .170$, article 78. 
legislation, this approach has permitted these groups to develop while respecting ICA philosophies and principles.

One trend observed in these business mergers is the considerable reduction in the rights and obligations of members whose relationship with the co-operative often comes to resemble that of mere clients/suppliers (Buendía 2002: 36).

In order to prevent isomorphic tendencies in mergers it is important to avoid the risks involved in a switch from a direct to a delegated democracy. Two such risks are bureaucratization, or the dominance of a technostructure which is not necessarily in agreement with members' interests, (Vargas 1999: 298) and the difficulties related to the joint legal contract in such cases. The merger must assure homogeneity among members according to their contributions to real flows as well as to finances whilst ensuring that responsibility for decisions taken depends on participation in co-operative activities and not on capital. They must further ensure that co-operatives which do merge maintain their rules even in those cases where segregations and splits would in fact facilitate the integration process.

Paradoxically however, this tendency towards demutualization has, in many countries, been encouraged by co-operative legislation itself. Such legislation has permitted the access of new elements which, while moving away from co-operative identity and practice, were introduced with the aim of facilitating access to the financial markets and guaranteeing enough flexibility to adapt to changes in circumstance.

Most legislative reforms regarding European co-operative societies have been aimed at encouraging access to capital markets by introducing new forms of financial resource mobilization, incorporating the participation of non-user members in social capital while establishing certain limits on these participants in order to avoid their taking control. (Buendía 2002: 40).

With this in mind, those countries where new legislation for co-operative societies has been recently adopted France (Law 92-643 of 13 July 1992), Italy (Law 142 of 3 April 2001), Spain (Law 27/1999, of 16 July), Belgium (Law 20 July 1991), Portugal (Law n. 51/1996 7 September), Finland (Co-operative Act 1488/2001) and Sweden (Law 11 June 1987), have in fact authorized investment by non-user third parties (European Commission 2001: 21) thus dangerously raising the percentage of capital ${ }^{15}$ in the hands of these financial members. In

15 This refers to additions of financial resources made by members of a cooperative society. 
some cases, such as those of the Spanish 'mixed co-operatives', the criteria for profit sharing is not based on co-operative action (as established by the ICA in the third co-operative principle of economic participation), but rather on the percentage of social capital held.

Financial input from external sources into the member capital of co-operatives is seen by some as a threat, a backsliding towards capitalist forms (Pflimlin 1998) while others regard it as an innovative instrument in financing co-operative growth. Whatever the outcome, it is nevertheless true to say that the exercising of political and economic rights on the part of these capitalist partners introduces an element of conflict due to the different interests of the various partners involved in the business (Lassen 1998). In this sense the co-operative is weakened by creating a relationship (albeit partially) between the right to vote and contributions made to capital (Celaya 1995: 116).

The European Union, in its awareness of the new challenges faced by co-operative societies and of the problems of isomorphism provoked when these reach a size comparable to a large-scale business, has encouraged the raising of capital from co-operative members from various EU states in order to develop cross-border activities through, and regulated by, the Statue for European Co-operatives (SCE). ${ }^{16}$

However, even though the statute aims to encourage transnational co-operation between physical persons or legal entities from different member states of the EU (SCE Statute, article 2), it has followed the tack of most national legislation in allowing for the existence of external (non-user) investors who contribute financially without participating in co-operative activity (SCE Statute, article 14.1) but limiting their voting rights to a maximum of 25 per cent of the total votes (SCE Statute, article 59.3). This legislation allows for such investors only when it is permitted in the co-operative legislation of the member state where the co-operative has its registered headquarters and when it is set out in its co-operative statutes.

The most dangerous aspect of this statute is that it does not limit the percentage of capital held by either user or non-user members. It would have created less risk of isomorphism a maximum limit had been set whereby the majority of a co-operative society's capital is held by those co-operative members who contribute financially and participate in the co-operative activity. If a limit is not set, the statute

16 Council Regulation (EC) No 1435/2003 of 22 July 2003 on the Statute for a European Cooperative Society (SCE). Official Journal of the European Union, l. 207/1 of 18.8.2003. 
in fact goes against the eventual aims of the SCE set out in its own explanatory statement: 'activities should be conducted for the mutual benefit of the members so that each member benefits from the activities of the SCE in accordance with his/her participation, members of the SCE should also be customers, employees or suppliers or should be otherwise involved in the activities of the SCE'.

Moreover, the co-operative principle of economic participation states that: 'members usually receive returns, when available, which are limited according to the capital submitted as a condition of membership', yet, article 67.2 of the SCE allows for a cooperative society to distribute the surplus remaining after allocations to the legal reserve and the payment of dividends as a return on 'paid-up capital and quasi-equity'. ${ }^{17}$ In this way, by not setting limits on the remuneration of member capital and being part of the profits, the return is brought into line with dividends distributed by conventional limited companies.

The SCE statute therefore aims to promote the interests of the non-user member in two ways: firstly by allocating voting rights and (given that this can be regarded as a form of control over investments) thus gain the confidence of the investor, and secondly by not limiting the possible returns on such participation.

The introduction of non-user members or investors without the establishment of certain limitations however, does imply an explicit recognition of the power of capital in co-operatives societies, a factor traditionally considered subordinate or instrumental (Pastor 2002: 113). It does so precisely in this current climate where the financial participation of the workforce in the returns of their companies either through direct participation in profits or through share in member capital is becoming a more widespread practice throughout Europe and is a process recognized by the Communication from the Commission to the Council on a framework for the promotion of employee financial participation. ${ }^{18}$

17 However, the explanatory statement would appear to be contradictory to 'the return on loan capital and share capital must be restricted'. The shares to which the legislator refers are understood to be in social capital, given that article 1.2 rules that: 'the subscribed capital of an SCE will be divided in shares'.

18 European Commission. Commission to the Council on a framework for the promotion of employee financial participation COM (2002) 364(01) y Bol. 7/8-2002. http://www.europa.eu.int/eur-lex/es/com/cnc/2002/com2002_ 0364es01.pdf 
Two contradictory movements have occurred in the European Union with respect to this matter. On the one hand, there exist different European Commission actions meant to encourage employee ownership; this coincides exactly with one of the genuine characteristics of co-operatives. And on the other hand, the SCE Statute, in opposition to traditional practices, allows unlimited participation to investor members who do not fulfil the double condition of member and user (workers and customers).

In any case the possibilities offered by the new statute are still little known and we will have to wait a while before being able to evaluate its effects and whether or not it has come up to expectations. The Regulation ${ }^{19}$ should come into force three days after its publication in the Official Journal. However, its date of application has been postponed until 18 August 2006.

\section{Towards co-operative micro-business}

Alongside the merger processes we find micro-business initiatives, i.e. business initiatives taken by less than ten members. ${ }^{20}$ They are distinct processes but both aim to respond, in different ways, to common factors. ${ }^{21}$ In the case of micro-businesses, this means developing economic activities which aim to encourage a local, rather than a global, identity.

Micro-business in its various forms is a phenomenon which aims to promote not only identity, as mentioned above, but also development on a more local scale as a strategy for adaptation which is both

19 Council Regulation (EC) No 1435/2003 ..., opus cit. Article 80: Entry into force - This regulation shall enter into force on the third day following its publication in the Official Journal of the European Union. It shall apply from 18 August 2006.

20 European Commission. Commission Recommendation, 6 May 2003, concerning the definition of micro, small and medium-sized enterprises, Official Journal of the European Union, L 124, 20 May 2003. http://www. europa.eu.int/eur-lex/pri/es/oj/dat/2003/1_124/1_12420030520es00360041.pdf.

Annex Title I, article 2: 'Within the SME category, a microenterprise is defined as an enterprise which employs fewer than 10 persons and whose annual turnover and/or annual balance sheet total does not exceed EUR 2 million.'

21 For instance, political, economic and legislative changes, technical advances, the privatizing of companies and public services. In the European sphere, the single currency has streamlined firms' decision-making procedures. 
dynamic and flexible but which is also firmly rooted in a particular territory. Also, it is a response to new business initiatives and to the abandonment, on the part of large businesses, community and national institutions, of the disadvantaged.

In this sense the European Union has underlined the important role played by co-operatives in regional development as well as their contribution to the generation and maintenance of employment in less developed economic areas. ${ }^{22}$ For this reason co-operative societies can be classified as excellent examples of local, small scale micro-businesses. The fact that they are a growing phenomenon only serves to highlight, above all, their capacity for business initiative (Prévost 1996).

According to the European Commission (2001: 11) new forms of co-operative societies have appeared in most of the member states mainly in sectors such as education, social and health services, rural development, company services and services based on knowledge sharing; and these are successful because of local factors and because of their co-operative nature. Many examples can be cited, such as teaching co-operatives in Spain, Portugal and Sweden (which bring together parents and/or teachers), E-commerce co-operatives in France and Italy (small handicraft companies which sell their products over the internet), or the social service co-operatives (which bring together socially excluded groups) of Belgium, France, Greece, Portugal or Italy.

In more general terms, stretching beyond the co-operative movement itself, the scope for Social Economy activities has widened in recent years in order to encompass new functions taken on by associative movements. This has led to the formation of initiatives for social reintegration (special employment centres, occupational workshops, partnerships etc.), responsible consumerism (consumer organizations, fair trade, etc.), the protection of the environment and rural development (ecological agriculture, bioclimatic architecture, recycling) and alternative financing methods (ethical funds, proximity savings, etc.) (Coque 2002: 65).

All of these are new experiences in micro-business which, in some cases, are brought about through co-operative societies and in other cases are not, but all of which stem from civil society itself as, in its quest to meet untended needs, it reinvents the Social Economy through spontaneous organization.

22 European Community. Resolution on the contribution of cooperatives to regional development. Official Journal of the European Union, n. ${ }^{\circ} \mathrm{C} 246$, 14 September 1987. 
One of the factors which has triggered all of these new co-operative micro-business initiatives has been the restructuring of the welfare state, which has been taking place since the end of the twentieth century. Changes in the forms of intervention by the welfare state have not led to a breaking down of its fundamental institutions (Rodríguez Cabrero 1991: 41) but rather to an opening up towards the collective production of welfare. ${ }^{23}$

In the context of the collective production of welfare, Social Economy organizations have shown themselves to be guarantors operating within the market because they have been able to provide answers to two important economic and social problems arising over the last twenty years: long term unemployment and social exclusion (Monzón 2003: 28).

The state ${ }^{24}$ promotes this kind of participative organization to try to improve services or to meet new social needs, although in most European countries the state continues to be the main thrust behind welfare and offers support to entities that are part of the Social Economy through public policies, financing, favourable legislation and institutional recognition.

For this reason the development of social welfare in Europe must involve a greater level of co-operation between the state and third sector organizations (Sätre 2001: 415) by attempting to limit public sector bureaucracy and promoting welfare policies which involve different forms of co-operation between them. Such is the case of the old people's homes in the UK, ${ }^{25}$ the non-profit making hospitals of Italy ${ }^{26}$ and the teaching co-operatives in Spain. ${ }^{27}$

23 Pluralism in Welfare is one of the welfare state reforms implemented during the eighties and nineties and which, according to Montoro Romero (1999: 179), has been the 'most successful and most forward thinking'.

24 Co-operative societies in Spain, Italy and Portugal enjoy explicit recognition in those countries' constitutions.

25 A study of this case can be found in: Kendall J. and Knapp M. (1999) 'The third sector and welfare state modernization : inputs, activities and comparative performance'. In: Muñoz S., García J.L. and González L. (Dres) Las estructuras de bienestar en Europa. Madrid: Civitas: 808-826.

26 For a detailed analysis see: Ranci C., The role of the third sector in welfare policy in Italy. In: Sarasa S. and Moreno L. (Coordinadores) El Estado de bienestar en la Europa del sur. Madrid: Consejo Superior de Investigaciones Científicas, pp. 187-213.

27 See: Fernández Guadaño J. (1999) 'Las sociedades cooperativas en la educación ante la nueva concepción del Estado en la provisión de servicios educativos', Revista de Estudios Cooperativos (REVESCO), n ${ }^{\circ}$ 67: 71-88. 
Of all the third sector organizations, it is the co-operative societies which most closely parallel the conventional private sector, their intrinsic power derived from their own nature places them, according to Defourny (1987: 27), in a highly favourable position from which to create laboratories of social innovation and distribution of power.

Although the co-operative movement in Europe has two centuries of experience behind it, it still receives mixed recognition from certain European countries. In spite of this, the co-operative model continues to present a series of advantages. According to Spear (2000: 521-522): '[the co-operative model] is effective in responding to market failures and state crises; provides a trust dimension in the provision of goods and services; builds upon self-help and solidarity within the community and enhances social capital; is participatory and they empower people and thereby make a more effective use of the resources; and has a greater social efficiency by generating positive externalities'.

The twin social and economic purposes that characterize co-operatives has led different economic agents to regard them as a viable alternative in the provision of certain social services and as a way to strengthen economic development with impairing the achievement of social objectives. These examples of good will or advantages cited earlier derive from respect for co-operative principles making the co-operative society an organization where participation by suppliers and/or consumers from every strand of the company reaches its maximum expression through democratic decision making, supplying work and using capital as a means to improve working conditions and not simply as an end in itself.

However, the less favourable treatment accorded to capital is the main source of difficulties in co-operative societies, which have been saved, in some cases, by organizing themselves into co-operative groups or by resorting to modern financial engineering techniques (Defourny 1987: 28). Others, such as those studied here, have been unable to follow this course of action and have ended in processes of isomorphism.

In spite of this, the co-operative model has great potential in community economic development, in fact co-operatives 'have also been central in maintaining services and employment in smaller communities in a socially responsible manner' (Wylie 2001: 14). For this reason co-operatives are expressly included in the European Employment Strategy. ${ }^{28}$ Moreover the European Commission (2001)

28 See: European Commission (2000) Acting Locally for Employment. A Local Dimension for the European Employment Strategy. COM (2000), 196 final, Brussels 7 April 2000. 
has underlined that in several member states there have been numerous initiatives to improve employment levels which have successfully used the co-operative formula. ${ }^{29}$

In conclusion, if the birth of co-operativism was a response on the part of civil society to industrialization, the new co-operative micro-business initiatives combine renovation with a return to origins, aiming to provide solutions, in collaboration with other economic actors, to aspects such as unemployment and social exclusion which constitute the problem of social cohesion in Europe.

\section{Conclusions}

For several years now the European co-operative movement has been developing through contrasting tendencies. On one hand, there has been growth through formulas which aim to group broadly incompatible capital assets whilst maintaining co-operative principles. On the other hand, there has been a tendency towards the creation of locally developed micro-businesses which encourage co-operative values such as participation and democracy.

Co-operativism does not receive equal importance or recognition in the different countries of Europe, nonetheless co-operative societies themselves face similar problems which are derived as much from context as from their own character.

In recent years the most mature co-operative sectors such as banking, agriculture or retail, have witnessed a high level of merger activities, from joint ventures to the creation of groups, which have led to so-called 'decooperativization or isomorphism', terms which attempt to illustrate the difficulties of synthesis faced by large scale co-operative societies in their efforts to balance successful operations with co-operative principles.

Such principles are jeopardized once co-operative societies undergo mergers which involve thousands of members who see how their rights and obligations are reduced to a minimum as their status as members begins to resemble more that of mere clients or suppliers. Likewise when, in order to finance co-operative growth processes, outside investors are sought to participate in member capital and

29 See document available on Internet: http://www.europa/comm/ employment_social/empl\&esf/3syst/index_en..htm. Last consulted [26th September 2003] 
are (in many cases) allocated economic and social rights to those of co-operative members. This tendency has often been fostered and encouraged in certain European countries by co-operative legislative reforms which have been reproduced in the recent European Co-operative Statute.

In order to try to avoid the isomorphism, it is necessary to focus on the full development of the cooperative principles, guarantee a legal framework that allows the cooperative societies to adapt to the changing conditions of the markets without losing their democratic nature.It is also important to overcome difficulties related to their legal form, the resulting business concentration should ensure three things: that a merger will permit homogeneity among members, in terms of their contributions not only to real flows but also their financial contributions; that decision-making is based on activities undertaken and not on capital; and that co-operatives which do merge respect their principles. Spain has offered a successful solution to this through the regulation of the different types of co-operative mergers.

Alongside these co-operative mergers, a multitude of microbusiness have been formed as co-operative societies as a different way of solving some of the classic problems such as employment in specific local environments or as a way of responding to new initiatives concerning rural development, the environment and social reintegration. Some of these experiences have been recognized by the European Commission thus confirming the capacity of co-operative societies to mobilize in the areas of local and community development, as well as demonstrating their capacity to move from traditional activities such as industry, construction or commerce towards new businesses such as co-operative societies offering social services.

At the present time these two processes co-exist although we will have to wait for the results of the new European initiatives such as the recent Statute on European Co-operatives before being able to analyse its future impact on both these tendencies.

\section{REFERENCES}

ARCHAMBAULT E., 1993 'Defining the Third Sector: France', Working Paper University Johns Hopkins. Baltimore.

BAGER T. 1994, "Isomorphic processes and the transformation of cooperatives", Annals of Public and Cooperative Economics, 65, 1, 35-57. 
BAREA J., JULIÁ, J.L. and MONZÓN, J.L., Dirs, 1999, Grupos empresariales de la Economía Social en España, Valencia: CIRIEC-España.

BELLEY M., 1988, "Les relations entre économie sociale, économie publique et économie privée. La dénve des coopératives au Québecn". In: Les systemes d'économie mixte dans les économies modernes. Actes du XV Congres du CIRIEC. Uége, pp. 131-141.

BUENDÍA MARTÍNEZ I., 2002, 'Tendencias cooperativas europeas: el desarrollo local y la desmutualización'. En: VARGAS A. and LEJARRIAGA, G.R. Dirs, Las empresas de participación en Europa: el reto del siglo XXI. En homenaje al Prof. Dr. Carlos García-Gutiérrez Fernández. Madrid: Escuela de Estudios Cooperativos, pp. 35-45.

CELAYA U.A., 1995, Acceso de las cooperativas al mercado de capitales. Mondragón: Instituto Nacional de Fomento a la Economía Social.

CHAVES R. 1997, 'Economía politica de la Economía social'. CiriecEspaña, n. ${ }^{\circ}$ 25: 141-162.

CHAVES R., DEMOUSTIER D., MÓNZÓN J.L. et al. Dirs, 2000, Economía Social y empleo en la Unión Europea. Acción Piloto 'Tercer Sistema y empleo' de la Comisión Europea. Valencia: CIRIEC-España.

COMISIÓN EUROPEA, 2000, Acting Locally for Employment. A Local Dimension for the European Employment Strategy. $\operatorname{COM}(2000), 196$ final, Bruselas 7 de abril de 2000.

COMISIÓN EUROPEA, 2001, Las cooperativas en la Europa de las empresas. Documento de consulta. Disponible en Internet: http:// www.europa.eu.int/comm/enterprise/entrepreneurship/coop/index.htm. Fecha de consulta [26 de agosto de 2003].

COMISIÓN EUROPA, 2002, Comunicación de la Comisión relativa a un marco para la participación financiera de los trabajadores, $\operatorname{COM}(2002)$ 364(01) y Bol. 7/8-2002. http://www.europa.eu.int/ eur-lex/es/com/cnc/2002/com2002_0364es01.pdf

COMISIÓN EUROPEA, 2003, Recomendación de la Comisión, de 6 de mayo de 2003, sobre la definición de microempresas, pequeñas y medianas empresas. Diario Oficial de la Unión Europea, L 124, de 20 de mayo de 2003. http://www.europa.eu.int/eur-lex/pri/es/oj/dat/ 2003/l_124/l_12420030520es00360041.pdf.

COMUNIDADES EUROPEAS, 1987, Resolución sobre la contribución de las cooperativas al desarrollo regional. Diario Oficial de 
las Comunidades Europeas (D.O.C.E), n. ${ }^{\circ} \mathrm{C} 246$, del 14 de septiembre de 1987.

COMUNIDADES EUROPEAS, 1994, Resolución sobre la contribución de las cooperativas al desarrollo regional. Diario Oficial de las Comunidades Europeas D.O.C.E), n. ${ }^{\circ} \mathrm{C}$ 61, del 11 de febrero de 1994.

COUNCIL REGULATION, 2003, No 1435/2003 22 July 2003 on the Statute for a European Cooperative Society SCE). Official Journal of the European Union, 1. 207/1 of 18.8.2003.

COQUE MARTÍNEZ J. 2002, 'Pasado, presente y futuro de las empresas participativas europeas'. En: VARGAS SÁNCHEZ A. and LEJARRIAGA G.R., dirs, Las empresas de participación en Europa: el reto del siglo XXI. En homenaje al Prof. Dr. Carlos García-Gutiérrez Fernández. Madrid: Escuela de Estudios Cooperativos, pp. 57-67.

DEFOURNY J., FAVREAU L. and LAVILLE J.L., 1997, 'Introducción a un balance internacional'. En: DEFOURNY J., FAVREAU L. and LAVILLE J.L. Dres, Inserción y nueva economía social. Un balance internacional. CIRIEC.

DEFOURNY J., 1994, 'Tres enfoques económicos de las asociaciones'. CIRIEC-España, n. ${ }^{\circ}$ 16, pp. 121-146.

DEFOURNY J. 1987, 'Orígenes, contextos y funciones de un tercer gran sector'. En: MONZÓN J.L. and DEFOURNY J., Dirs, Economía social: entre economía capitalista y economía pública. Valencia: CIRIEC-España.

DEMOUSTIER D., 2000, 'Análisis del empleo'. En: CHAVES R.; MONZÓN J.L. et al., Economía Social y empleo en la Unión Europea. Acción piloto 'Tercer sistema y empleo en la UE'. Valencia: CIRIEC-España, pp.51-76.

FERNÁNDEZ GUADAÑO J., 1999, "Las sociedades cooperativas en la educación ante la nueva concepción del Estado en la provisión de servicios educativos". Revista de Estudios Cooperativos (REVESCO), 67, pp. 71-88.

GARCÍA-GUTIÉRREZ F.C., 1994, 'La concentración económicoempresarial los conglomerados) de sociedades cooperativas', en: V.V.A.A. Las empresas públicas sociales y cooperativas en la nueva Europa. XIX Congreso Internacional de CIRIEC. Valencia: CIRIECEspaña, pp. 419-442.

GARCÍA-GUTIÉRREZ F.C., 1991, 'La economía social o la economía de las empresas de participación las sociedades cooperativas y 
laborales)'. En Memoria de María Angeles Gil Luezas. Madrid: Alfa Centauro, pp. 195-216.

HANSMANN H., 1987, 'Economic theories of nonprofit organization', Yale Law Journal, 89, 835-901.

INTERNATIONAL COOPERATIVE ALLIANCE, 1995,. The International Co-operative Alliance Statement on the Co-operative Identy, 1995. Manchester: International Cooperative Alliance (XXXI Congress International Cooperative Alliance). Available on Internet: http://www.ica.coop/ica/es/esprinciples.html. Last consulted [31th January 2005]

INTERNATIONAL COOPERATIVE ALLIANCE, 1998, Statistics and information on European co-operatives. Géneva.

INTERNATIONAL LABOUR OFFICE, 2002, Text of the recomendattion concerning the promotion of the cooperatives submitted by the drafting committee, (90th session). Geneva: International Labour Office.

KNAPP M. et al., 1990, 'Public money, voluntary action: whose welfare?', In ANHEIER H. and SEIBEL W.. (eds) The Nonprofit Sector: International and Comparative Perspectives, NewYork: de Gruyter.

KENDALL J. and KNAPP M., 1999, 'Modernización del tercer sector y del Estado de Bienestar: aportaciones, actividades y rendimiento cooperativo'. En: MUÑOZ S., GARCÍA, J.L. and GONZÁLEZ L. (Dirs) Las estructuras de bienestar en Europa. Madrid: Civitas, pp. 808-826.

LASSEN B.C., 1998, "External capital - a treat to the ideas and objectives of co-ops?", Review of International Cooperation, 91, 3, 41-46.

MONZÓN CAMPOS J.L., 2003, 'El cooperativismo en la historia de la literatura económica'. CIRIEC-España, n. 44, pp. 9-32.

MONTORO ROMERO R., 1999, 'El estado de bienestar moderno'. En: En: MUÑOZ S., GARCÍA J.L. and GONZÁLEZ L. (Dirs) Las estructuras de bienestar en Europa. Madrid: Civitas, pp. 131-182.

PARRA DE MAS S., 1974, La integración de la empresa cooperativa. Madrid: Editorial de Derecho Financiero.

PASTOR SEMPERE, M.C., 2002, Los recursos propios en las sociedades cooperativas. Madrid: Derecho Reunidas.

PFLIMLIN E., 1998, "Demutualisation of financial co-operatives", Review of International Cooperation, 91, 3, 47-53.

PRÉVOST P. 1996, El desarrollo local y las cooperativas. Cuadernos de Desarrollo Rural, n. ${ }^{\circ} 37$, segundo semestre, pp. 25-45. 
RANCI C., 1995, 'El papel del tercer sector en las políticas de bienestar en Italia'. En: SARASA S. and MORENO L.. (Coords) El Estado de Bienestar en la Europa del sur. Madrid: Consejo Superior de Investigaciones Científicas.

RODRÍGUEZ CABRERO G., 1991, "La división social del bienestar: posibilidades y límites de la gestión mixta del Estado de Bienestar", Economistas, 51, 42-47.

SÄTRE A.M., 2001, “The social economy: new co-operatives and public sector", Annals of Public and Cooperative Economics, 72, 3, 413433.

SPEAR R., 2000, "The cooperative advantage", Annals of Public and Cooperative Economics, 71, 4, 507-523.

UNITED NATIONS, 2004, Cooperatives in social development. Resolution adopted by de General Assembly (on the report of the Third Commitee A/58/497 (Part II)). Fyfty-eighth session. 19 January 2004.

VARGAS SÁNCHEZ A., 1999, 'Claves de la excelencia en la gestión de sociedades cooperativas', En: PRIETO JUÁREZ J.A. (Coordinador) Sociedades cooperativas: régimen jurídico y gestión económica. Madrid: Ibidem Ediciones, pp. 285-303.

VIVET D. and THIRY, B., 2000, Campo de estudio, importancia cuantitativa y acepciones nacionales. En: CHAVES R., DEMOUSTIER D., MÓNZÓN J.L. et al. (Dirs) Economía Social y empleo en la Unión Europea. Acción Piloto 'Tercer Sistema y empleo' de la Comisión Europea. Valencia: CIRIEC-España.

WYLIE L., 2001, European Social Cooperatives: A Survey and Analysis of Current Developments. Canada: British Columbia Institute for Co-operative Studies.

\section{Changements structurels dans l'évolution des sociétés coopératives européennes}

Malgré leur longue expérience, les sociétés coopératives sont très diffénemment reconnues au sein des pays européens. Les instances supranationales comme la Commission européenne, l'ONU ou l'OIT ont reconnu l'importante contribution des sociétés coopératives à la création d'emploi et à la mobilisation de ressources en particulier au plan local. Deux tendances différentes ressortent néanmoins depuis plusieurs années dans le développement du secteur coopératif qui sont analysées dans cet article. L'une consiste en la création de processus de 
croissance via des formules rassemblant des détenteurs de capitaux difficiles à accorder avec le respect de certains principes coopératifs. L'autre tendance consiste à la création de micro-entreprises qui opèrent au plan local et qui rendent possible le développement territorial via la mobilisation de ressources locales sur base d'une origine locale des membres et d'une participation démocratique.

\section{Strukturelle Veränderungen in der Entwicklung von europäischen genossenschaftlichen Gesellschaften}

Trotz des Reichtums an Erfahrung, über den genossenschaftliche Gesellschaften verfügen, haben sie keine einheitliche Anerkennung in Europa gefunden. Supranationale Behörden wie die Europäische Kommission, die UNO und die ILO haben den wichtigen Beitrag hervorgehoben, der von genossenschaftlichen Gesellschaften bei der Schaffung von Arbeitsplätzen und der Mobilisierung von Ressourcen insbesondere auf lokaler Ebene geleistet wurde. Seit nunmehr zwei Jahren werden jedoch in der Entwicklung der europäischen Genossenschaftsbewegung zwei unterschiedliche Tendenzen deutlich, und diese werden in dieser Studie analysiert. Die eine geht in die Richtung, Wachstumsprozesse durch Formeln zu bewirken, welche darauf abzielen, Anteilseigner unter einem Dach zusammenzubringen, die ihrem ganzen Wesen nach schwierig zusammenpassen, und dabei versuchen, bestimmte genossenschaftliche Prinzipien aufrecht zu erhalten. Auf der anderen Seite gibt es eine Tendenz, kleine Gesellschaften zu gründen, die auf lokalen Märkten agieren und die territoriale Entwicklung durch Mobilisierung lokaler Ressourcen, auf der Grundlage lokaler Bindung der Partner sowie demokratischer Partizipation, ermöglichen.

\section{Cambios estructurales en la evolución de las sociedades cooperativas europeas}

Aunque las sociedades cooperativas cuentan con una larga experiencia, sin embargo, su reconocimiento varía mucho entre los distintos países europeos. En instancias supranacionales como la Comisión Europea, la ONU o la OIT se ha destacado la importante contribución de las sociedades cooperativas en la creación de empleos y en la movilización de recursos sobre todo en el ámbito local. No obstante, se ponen de manifiesto desde hace años en el desarrollo del movimiento cooperativo europeo dos tendencias diferentes que se analizan en este trabajo, una 
hacia procesos de crecimiento mediante fórmulas que pretenden concentrar patrimonios de difícil síntesis con el mantenimiento de algunos principios cooperativos, y por otro lado, una tendencia hacia la creación de microempresas que actúan en ámbitos locales y que potencian el desarrollo territorial mediante la movilización de recursos autóctonos sobre la base de la adscripción local de los socios y sobre una participación democrática. 


\section{NEW TO BLACKWELL PUBLISHING IN 2005}
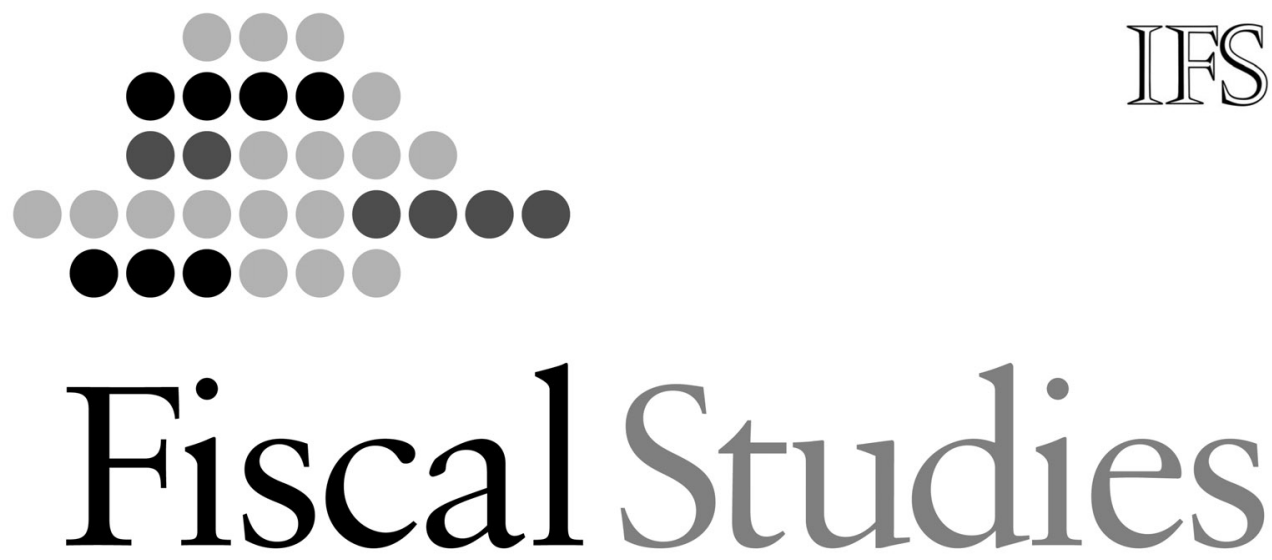

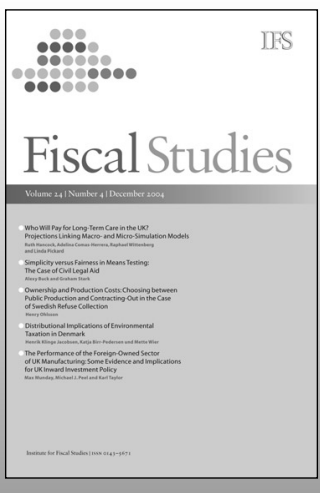

Recent Highlights

Unemployment and workers'

compensation programmes: Rationale design, labour supply and income

support

Bruce D. Meyer

Annuity markets and retirement security James M. Poterba

Public and Private Spending for Environmental Protection: A Cross-

Country Policy Analysis

David Pearce, Charles Palmer

Educational Inequality: The Widening

Socio-economic Gap

Stephen Machin, Anna Vignoles

Credible Pensions

Tim Besley, Andrea Prat

In The September Issue

Public Service Broadcasting

Mark Armstrong

Welfare to Work, Wages and Wage

Growth

Reamonn Lydon, Ian Walker
EDITORS

Production EDITOR

Leading forum for debate on public economics and fiscal policy

\section{Papers written by experts in public policy worldwide}

- Clear and accessible for a broad international audience

Since its inception in 1978, Fiscal Studies has earned a reputation around the world for publishing high-quality, original research papers in a style understandable to a wide audience. Written by leading experts in public economics and fiscal policy worldwide, articles are presented in a clear and accessible format which will appeal to a broad international readership of policy-makers, public finance practitioners and academic researchers.

Fiscal Studies offers readers a wide perspective on the whole spectrum of ways in which government action affects the private sector. Papers published in 2004 covered a broad range of topical issues of worldwide concern including studies into educational inequality, debt in low-income families and welfare-to-work programmes.

Fiscal Studies is the journal of The Institute for Fiscal Studies. The journal was started by researchers at the Institute and aims to bridge the gap between academic research and policy. It seeks to provide a forum for material which is accessible to a wider audience than that of academic journals in economics. The journal's editors are drawn from among the Institute's own research staff and from its Fellows and Associates, leading academics in the field.

Fiscal Studies is now available online via Blackwell Synergy, Blackwell Publishing's state-of-the-art online journals service. To sign up for a free email alert each time a new issue of Fiscal Studies is published online, simply register at

www.blackwell-synergy.com

\section{www.blackwell-synergy.com/links/toc/fisc}

